У,AK 331

ББК 65.24

DOI 10.22394/1682-2358-2017-3-88-94

A.V. Rastegaeva, postgraduate student of the Economic Sociology, Advertising and Public Relations Department, Saratov SocioEconomic Institute of the Plekhanov Russian University of Economics

\section{DEPROFESSIONALIZATION OF LABOR RESOURCES IN MODERN RUSSIA}

The article explores the essence of deprofessionalization of labor resources in the Russian labor market, analyzes its causes and consequences. The author shows that this phenomenon is a problem of national importance that threatens national security. Measures to regulate the labor market, aimed at overcoming the tendency towards the deprofessionalization of labor resources are proposed.

Key words and word-combinations: deprofessionalization, labor resources, labor market, professional mobility
A.B. Pacmezaeba, аспирант кафедрь экономической сочиологи, рекламь и связей с обиестьенностью Саратовского сочиально-экономического института (филиала) Российского экономического университета имени Г.В. Плеханoba (email: golannavl@yandex.ru)

\section{АЕПРОФЕССИОНААИЗАЦИЯ ТРУАОВЫХ РЕСУРСОВ В СОВРЕМЕННОЙ РОССИИ}

\begin{abstract}
Аннотация. Исследуется сущность депрофессионализации трудовых ресурсов на российском рынке труда, анализируются ее причины и последствия. Автор доказывает, что данное явление представляет собой проблему общегосударственного значения, несет угрозу национальной безопасности. Предлагаются меры по регулированию рынка труда, направленные на преодоление тенденции к депрофессионализации трудовых ресурсов.
\end{abstract}

Ключевые слова и словосочетания: депрофессионализация, трудовые ресурсы, рынок труда, профессиональная мобильность.

овременное состояние рынка труда в Российской Федерации, его Аинамика и основные процессы, происходившие в сфере занятости населения в последние годы, весьма подробно освещались многими исследователями. Вместе с тем недостаточно внимания уделялось такому явлению, как Аепрофессионализация трудовых ресурсов. В работах, посвященных рынку труда современной России, Аанное явление если и упоминается, то косвенно, в контексте анамиза иных явлений. По нашему мнению, 
вопросы депрофессионализации трудовых ресурсов, ее причин и значения для экономики и сощиальной сферы требуют серьезных научных изысканий.

Следует, однако, признать, что термин «депрофессионализаџия» в послеАние годы встречается в научных трудах все чаще. Хотя он приобретает весьма различные, подчас неблизкие значения - от экономических до этических. К примеру, Н.А. Мартьянова и М.В. Рубцова отмечают, что под ним понимают и падение престижа профессии, и снижение уровня профессионализма, и пересмотр критериев профессиональной этики, и подмену профессионального знания экспертным мнением, и даже кризис профессии в условиях постмодерна [1, с. 20] .

Аепрофессионализация как явление макроэкономическое и макросоџиомогическое выделена А.Н. Кочетовым относительно недавно [2] . Согласно его заключениям депрофессионализация населения выявляется на рынке труда по определенным параметрам. Во-первых, в профессионально-квалификационной структуре рабочих мест в системе занятости происходит регресс из-за того, что экономика превращается в сырьевой придаток по причине подавцяющего преобцадания простых рабочих профессий. Во-вторых, растет невостребованность интемлектуального потенциала - вплоть до того, что вузы становятся одними из основных каналов безработиџы; стремительное распространение получает такое негативное в массе явление, как работа не по специальности.

По версии А.Н.Кочетова, депрофессионализация - «это в первую очередь утрата профессии или уровня квалификации, а не только снижение спроса на высококвалифиџированные профессии. При увеличении числа мюдей, приобретающих профессию, на которую не имеется достаточного спроса, увеличивается и показатель депрофессионализации» [3, с. 64] .

ГАавный показатель дисбаланса соџиально-профессиональной структуры занятости населения - то, что обладатели высшего образования вытесняют с рабочих мест, где не требуются особые знания, работников с более низким уровнем квалификации.

Все привычнее становится работать не по специальности. ОАнако это не просто скрывает формальное несоответствие между квалификаџией, полученной при обучении, и реальным характером труда, а отражает проявление более глубокого процесса формирования определенного социального слоя, который А.Н. Кочетов обозначил как «мюмпен-специалисты» [3, с. 65], а Ж.Т. Тощенко назвал «прекариатом» $[4$, с. 3]. Прекариат, по его определению, - это мюди, постоянно занятые временной, эпизодической работой, которые составмяют неформальный сектор рынка труда. Эти мюди, как правило, ограничены в соџиальных правах и, соответственно, обцадают ущемленным социальным статусом.

Каковы основные причины депрофессионализации населения? Труд явцяется одним из факторов производства и, соответственно, развивается по основным закономерностям формирования спроса и предложения на результаты производства. Спрос на труд непосредственно зависит от спроса на товары или услуги, при производстве которых он затрачивается. Размичные товары и услуги производятся с использованием разных видов труда, и это проявАяется в профессионально-квалификационной структуре спроса на труА. 
Аюди стараются адаптироваться к условиям рынка труда. Происходит это, как правицо, путем межпрофессиональной миграции. Гцавной мотиваџией Аля нее явцяется относительно высокий уровень Аохода, который отодвигает на второй план работу по специацьности, удовцетворенность характером и содержанием труда. Межпрофессиональная мобильность рабочей силы нередко происходит с потерей профессиональной квалификации. Если же смена рода занятости становится частой, а тем более постоянной, то работник, по мнению Ж.Т. Тощенко, становится представителем прекариата. Важно, что частая смена профессий - не внутренняя потребность, а киния поведения, навязанная, как полагает Ж.Т. Тощенко, «неолиберальной экономикой».

А.В. Черемошкина, рассуждая о сути и причинах депрофессионализации трудовых ресурсов в России, выделяет три волны этого явления [5, с. 59], первая из которых датируется концом 1980-х - началом 1990-х годов. Этот период автор называет «точечной» депрофессионализацией, вызванной кризисными процессами, происходившими в те годы в государстве, обществе, экономике, когда исчезали мибо претерпевали радикальный регресс целые отрасли производства. Соответственно, серьезно изменилась и мотивация профессиональной деятельности: наА внутренними мотивами - такими, как радость созидания, творчество, самореализация - повсеместно стали Аоминировать мотивы, внешние по отношению к процессу деятельности.

1990-е годы А.В. Черемошкина называет второй волной депрофессионализации, указывая, что приметами этого времени стало «распыление профессионалов», а также маргинализация многих социально значимых видов труда, в том числе управленческой сферы. В результате не только произошло снижение количественных и качественных показателей трудовых ресурсов, но и возникма угроза возможности их дальнейшего воспроизводства [5, с. 61]. Специамисты во многих сферах стали массово утрачивать свою профессиональную идентичность. Это выражалось в безразцичном, индифферентном отношении к своим обязанностям, к принятым в профессии нормам и правицам, вплоть Ао вытеснения профессионацьной этики иными ценностями и целями.

Начало XXI в. в России ознаменовалось экономическим ростом. Казалось бы, депрофессионацизаџия Аолжна пойти на спаА. ОАнако этого не произошмо. Третья волна депрофессионацизации (с начала 2000-х годов по настоящее время), по А.В. Черемошкиной, не только сохранила уже сформировавшиеся негативные тенденџи, но и породияа новые. Произошла почти повсеместная трансформация оџенки качества профессионального труда. Субъективизм работодателей вместе со стремлением работников к мичной корысти девальвироваци понятие «эффективный труА» [5, с. 63]. Кроме того, как указывает А.А. Перевезенцев, «процессы перерождения профессионального самосознания усугубцяются отсутствием системы профориентации, профотбора и профконсультации, отсутствием системы стимулирования трудовой активности и наличием множества ограничений карьерного роста» [6] .

В начале 2000-х годов рост экономического развития России только усициц структурный дисбаланс системы занятости [7, с. 35]. На первый взгляА, не

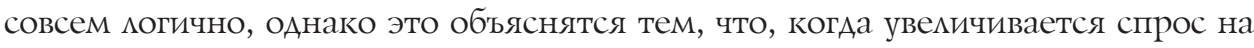


квалифицированных спеџиалистов, увеличивается и несоответствие качественного состава рабочей силы и профессионально-квалификационной структуры рабочих мест. По сути, в 1990-е годы причины депрофессионализации межали в экономической сфере, а в 2000-х они сконџентрировались в сфере профессионального образования.

Предложение на рынке труда и его потенщиал формируется за счет числа выпускников вузов. В свою очередь, работодатели, не имея достаточного комичества рабочих мест, требующих сложного труда, предъявляют слишком высокие профессионально-квалификаџионные требования к соискатемям. В результате абитуриенты и учреждения профессионального образования получают цожные сигналы о том, что на рынке труда высока потребность в специалистах с высшим образованием (которые нередко имеют этот статус мишь формально). Как следствие, при отборе на работу определяющим становится наличие Аиплома об образовании, причем оказывается неважно, какое это образование, какую профессию получиц человек. Таким работодателям фактически не нужна профессиональная квалификаџия работника. Большинство выпускников вне зависимости от полученной специальности осушествляют некий набор усредненных действий, Аля реализации которых не обязательно иметь высшее образование: выполнение поручений, сбор необходимых данных, подготовка исходной информаџии и т.п. Происходят массовая депрофессионализаџия, утрата профессиональной идентичности, потеря профессиональной культуры.

К сожалению, есть основания утверждать, что третья волна депрофессионализции в России продолжается. Не по специальности работает все больше и больше мюдей. По некоторым данным, если в 1995 г. только 17,6\% граждан не могли устроиться по своей профессии, то в 2002 г. их было 37\%, а в 2013 г. - уже 49,1\% $[8$, c. 55$]$.

Тот факт, что большой процент граждан получает высшее образование, нельзя оценивать мишь позитивно. С оАной стороны, более высокий уровень образования способствует повышению соџиального статуса индивида, его культурного уровня, его потенциальной профессиональной мобильности, конкурентоспособности на рынке труда. С другой стороны, возникает угроза того, что труа Аипломированных спеџиалистов и бакалавров будет использоваться неэффективно. Существует масса профессий, Аля получения которых вполне хватает одного-двух иет обучения (медицинские сестры, работники туристического и рекламного сервиса, техники и Ар.). Подготовка таких каАров стоит ошутимо дешевле, чем специалистов высокой квалификаџии, при этом их труа всегда востребован.

По сути, депрофессионализация насемения сегодня - прямое следствие того, как формировался и развивался рынок профессионального образования России в течение последнего двадџатилетия. САожившиеся отношения российского рынка образовательных услуг и рынка труда нельзя назвать согласованными.

Понижение спроса на работников в промышиенной сфере отрицательно повлияло на положение учреждений профессионально-технического образо- 
вания. В 1990-х годах перестройка системы профессионального образования значительно запаздывала, что усугубило положение в сфере промышиенности. В послеАние годы увеличивается дефиџит высококвацифиџированных рабочих каАров, который может усициться при экономическом росте.

Еще одна причина депрофессионализаџии трудовых ресурсов - слишком активный рост популярности неформальной занятости, которая часто воспринимается как последствие Алительной скрытой безработицы. Неформальная занятость в России определена относительно недавно, ее распространенность оџенивается противоречиво. В 2001 г. Госкомстатом России были разработаны «Методологические положения по определению и измерению занятости в неформальном секторе» [9]. В соответствии с этими положениями неформацьная занятость охватывает все формы оплачиваемой занятости по найму и не по найму, которые формально не зарегистрированы, не учитываются статистикой преАприятий и налоговыми органами, не подлежат регулированию и не защищены существующими правовыми структурами. По Аанным ВНИИ труда Минтруда России, в III квартале 2016 г. доля занятых в неформальном секторе составила 22,3\% от количества всех работающих гражкан. Это на 2\% больше, чем в конце 2015 г., и на 5\% - чем в конџе 2014 [10]

Относительно новой причиной Аепрофессионализации трудовых ресурсов явмяется распространение заемного труда по мизинговой схеме. На практике сегодня заемный труА используется Аостаточно широко, однако отсутствует правовое регулирование скмадывающихся отношений, что оказывает негативное вмияние на уровень защиты прав заемных работников, равно как и на мотивацию повышать уровень собственного профессионализма.

Распространение вторичной и неформальной занятости помогает замещать вертикальную восходящую сощиально-профессиональную мобильность в системе соџиацьно-профессионацьной стратификации горизонтацьной экономической мобильностью. ААаптивное к рыночной экономике и «экономически мобицьное» поведение связывается с проџессом приспособления к новой системе ценностей, которая возникает под воздействием изменений в экономической сфере. Но при этом возникает противоречие между ориентацией на прежний статус, индивидуацьный успех, материальное благосостояние и социальную защищенность. Вторичная и неформальная занятость в таком контексте проявляется как нисходящая профессиональная мобильность, ведущая к депрофессионализации. Вместе с тем именно она обеспечила «выживание» россиян в период рыночных трансформаций 1990-х годов, а также адаптацию к серии экономических кризисов 2000-х.

На то, что депрофессионализация населения в России продолжается, косвенно указывает и Ж.Т. Тощенко [4, с. 11]. Он отмечает, что потенциальными представителями прекариата выступают работники многих сфер деятельности - тех, с которыми необоснованно заключаются краткосрочные Аоговора, и это практикуется во все возрастающих масштабах под преАлогом «оптимизации».

Социальные последствия депрофессионализаџии выражаются в расширении маргинальных слоев населения, росте количества не только мюмпен-про- 
цетариата, но и мюмпен-специалистов, прекариата. Все больше работников пребывают в «подвешенном» состоянии, образуя значительную по численности группу трудоспособного населения, которую нестабильность и неустойчивость собственного соџиального положения волнуют много больше, чем вопросы воспроизводства собственной профессиональной компетенщии. Поскольку у таких граждан отсутствуют хотя бы минимальные перспективы обеспеченности жизни в будущем, особенно после завершения трудовой деятельности, существенно меняется их отношение к труду. Чтобы удержаться на плаву, сохранить работу и получить чуть больше, Аюди работают на износ, игнорируя санитарные и гигиенические нормы. Перегрузки приводят к профзаболеваниям, утрате здоровья, моральному и физическому истощению человека. Как отмечает Ж.Т. Тощенко, в сияу такого состояния этот слой населения не может быть базой социальной подлержки действующей власти [4, с. 11]. Более того, он обязательно будет искать выход из своего неопределенного положения, действуя сначала спонтанно, а в перспективе и организованно.

Экономические последствия депрофессионализации трудовых ресурсов дмя государства очевидны. Это как минимум снижение темпов роста ВВП, производительности труда и Аругих основных макроэкономических показателей развития, снижение конкурентоспособности мюбых производственных отраслей государства на мировом рынке, падение уровня и качества жизни населения.

Как видим, депрофессионализация трудовых ресурсов представмяет собой пробцему общегосударственного значения, несет угрозу национальной безопасности. Соответственно, решением этой проблемы необходимо заниматься на государственном уровне. Наиболее перспективными мерами по регулированию рынка труда, направленными на преодоление тенденџии к депрофессионализаџии трудовых ресурсов, представляются следующие.

Во-первых, борьба с размичными видами неформальной занятости - теневой, вторичной, заемным трудом и т.п. Эта борьба должна включать комплекс мер, среди которых как прямые административные запреты, так и экономическое стимулирование - повышение минимального размера оплаты труда до уровня прожиточного минимума, установление в бюджетной сфере тарифных сеток, соответствующих уровням квалификации и занимаемым Аолжностям, налоговое стимулирование формальной занятости. Кроме того, требуется обесепечить ухоА от распространившейся практики необоснованного заключения срочных Аоговоров.

Во-вторых, ужесточение государственного контроля условий труда: мимитирование продолжительности рабочего Аня, соблюдение техники безопасности, охрана труда и т.п.

В-третьих, модернизаџия системы профессионального образования. Необходима государственная программа восстановления почти полностью утраченной системы начального профессионального образования, включающая реанимацию образовательных учреждений (профессиональных училищ, миџеев и т.п.); подготовку соответствующих образовательных программ и преподавательских каАров; создание системы профориентаџии, профотбора и профконсультации в средних и старших классах школы. 
В-четвертых, разработка профессионально-квалификационных стандартов профессий и должностей, а также системы государственной профессиональноквалификационной аттестации с присвоением профессиональных разрядов.

Предлагаемые меры, направленные на преодоление тенденции к депрофессионализации трудовых ресурсов, явцяются приоритетными, но Аалеко не исчерпывающими. Основной стратегической целевой установкой государства в сфере регулирования рынка труда домжно стать создание максимально благоприятных условий для обеспечения работой всех граждан, желающих работать.

\section{Библиографический список}

1. Мартьянова Н.А., Рубиова М.В. Управляемость профессии как социального института: от депрофессионализации к реконструкции профессий // Studia Humanitatis. 2015. № 2. C. 20-24.

2. Кочетов А.Н. Рост образования и депрофессионализация населения на рынке труда // Материалы II Всероссийского социологического конгресса. Российское общество и социология в XXI веке. М., 2004.

3. Кочетов А.Н. Занятость специалистов: феномен невостребованности: Историко-социологический аспект. Саратов, 2013.

4. Тощенко Ж.Т. Прекариат: новый социальный класс // Социологические исследования. 2015. № 6. C. 3-13.

5. Черемошкина Л.В. Трудовые ресурсы: проблема депрофессионализации // Кадровый менеджмент. 2010. № 9. С. 59-67.

6. Перевезенцев А.A., Перевезенцева E.C. Анализ рынка труда РФ накануне и в период экономического кризиса. URL: http://www.mce.su/rus/archive/doc57354/

7. Лайкам К. Структурный анализ занятости и безработицы // Человек и труд. 2010. № 8. C. 34-41.

8. Воловская Н.М., Плюснина Л.К., Русина А.В., Иноземиева А.В. Незанятое население и самозанятость в сибирском регионе // Социологические исследования. 2015. № 5. С. 52-60.

9. Об утверждении Методологических положений по измерению занятости в неформальном секторе экономики: постановление Госкомстата РФ от 25 окт. 2001 г. № 76. URL: http:// docs.cntd.ru/document/901807158

10. Беришвили Н. Пятая часть работающих ушла в тень. Неформальная занятость в российской экономике продолжает расти. URL: http://izvestia.ru/news/655163 